\title{
Yellow Lupine Cyclophilin Transcripts Are Highly Accumulated in the Nodule Meristem Zone
}

\author{
Katarzyna Nuc, ${ }^{1}$ Przemysław Nuc, ${ }^{1,2}$ and Ryszard Słomski ${ }^{1}$ \\ ${ }^{1}$ August Cieszkowski University of Agriculture, Department of Biochemistry and Biotechnology, \\ ul. Wołyńska 35, 60-637 Poznań, Poland; ${ }^{2}$ Adam Mickiewicz University, Institute of Molecular Biology \\ and Biotechnology, ul. Międzychodzka 5, 60-371 Poznań, Poland \\ Submitted 10 April 2001; Accepted 6 September 2001.
}

\begin{abstract}
Cyclophilin (CyP) is one of the enzymes that act as peptidylprolyl cis-trans isomerases (EC 5.2.1.8). The cDNA and an intronless gene coding for cytosolic CyP have been isolated from yellow lupine. The deduced amino acid sequence of the characterized open reading frame shows approximately $80 \%$ homology with cytosolic CyP from other organisms. Southern blots of genomic DNA indicate that there is a small family of genes for CyP-related genes in the yellow lupine genome. RNA blot analyses demonstrate that $\mathrm{CyP}$ genes are expressed in all plant organs. The amount of CyP transcripts is dramatically increased in root nodules. In situ hybridization experiments indicate that $\mathrm{CyP}$ transcripts are localized mainly in meristematic tissues, with the highest level observed in the nodule meristem zone. The promoter of the sequenced gene contains $5^{\prime}$ AAAGAT $3^{\prime}$ and AT-rich motifs that are characteristic for some nodulin promoters.
\end{abstract}

Additional keywords: gene structure, symbiosis.

Cyclophilins (CyPs) constitute a large class of highly conserved ubiquitous peptidylprolyl cis-trans isomerases (PPIases) (EC 5.2.1.8; Fisher et al. 1989) that, together with FK560 binding proteins (FKBP) (Galat 1993) and parvulins (Rahfeld 1994), belong to a superfamily named immunophilins. These three classes of proteins are easily distinguishable by their selective interactions with immunosuppressive drugs. CyPs are targets for cyclosporin A (CsA) (Handschumacher et al. 1984), parvulins bind juglone (5-hydroxy-1.4-naphthoquinone) (Hennig et al. 1998) and FKBP are inhibited either by the FK560 drug or by rapamycin (Siekierka et al. 1989). Despite the lack of structural similarity, all these proteins have been shown to act as PPIases. In all cases, binding of the drug inhibits their PPIase activity (Schreiber 1991). In addition, some cytosolic CyP exhibit nuclease activity (Montague et al. 1994) that is not inhibited by cyclosporin (Montague et al. 1997). Their distinct isoforms have been localized in the cytoplasm (Schreiber 1991), nucleus (Ryffel et al. 1991), mitochondria (Matouschek et al. 1995; Rassow et al. 1995), chloroplasts (Luan et al. 1994), and endoplasmic reticulum (Price et al. 1991). The molecular mass of CyP varies between 18

Corresponding author: Katarzyna Nuc; E-mail: ktnuc@owl.au.poznan.pl

Nucleotide sequence data reported are available in the EMBL/GenBank/ DDBJ databases under accession numbers Y16088 for cDNA and AF178458 for gene. and $21 \mathrm{kDa}$, but a few complex CyP of high molecular mass have also been detected (Fulgosi et al. 1998; Wu et al. 1995). CyP transcripts accumulate in response to various biotic and abiotic stress conditions, e.g., wounding, heat shock, elevated salt concentration, and low temperature treatment (Marivet et al. 1994; Sykes et al. 1993). It has been shown that isomerization around Xaa-Pro bonds is one of the most limiting steps in protein folding, and this process can be accelerated by the PPIase activity of the CyP in vitro (Freskgard et al. 1992) and, possibly, in vivo (Baker et al. 1994). Several proteins are proposed to be substrates for CyP, e.g., rhodopsin 1 (Baker et al. 1994) and dihydrofolate reductase (Matouschek et al. 1995). Other proteins, like Gag polyprotein of human immunodeficiency virus HIV-1 (Franke et al. 1994; Luban 1996; Luban et al. 1993) and VirD2 endonuclease from Agrobacterium tumefaciens (Deng et al. 1998), were shown to interact with $\mathrm{CyP}$, but the exact function of $\mathrm{CyP}$ in these interactions is not clear.

Legumes specifically interact with symbiotic soil bacteria of Rhizobium and Bradyrhizobium genera. As a result of this interaction and under conditions of nitrogen limitation, plants form root nodules in which symbiotic forms of the bacteria, bacteroids, fix atmospheric dinitrogen and provide it to the plant host for assimilation. Nodulation involves an enhanced expression of certain plant genes (Keen et al. 1999). These genes are referred to as early- or late-nodulin genes (Udvardi 2001; van Kammen 1984). Protein products of early nodulin genes are involved in the infection process and nodule ontogeny; products of expression of late-nodulin genes are generally responsible for nodule functions (de Bruijn and Schell 1992; Nap and Bisseling 1990; Pichon et al. 1994). Many nodulin genes encode hydroxyproline-rich glycoproteins (HRGP) and proline-rich proteins (PRP) (Arsenijević-Maksimović et al. 1997; Munoz et al. 1996; Sherrier and VandenBosch 1994; Wilson et al. 1994). Although the function of these proteins remains unknown, it has been proposed that some of them are cell wall components, modifying the cell wall structure and the infectibility of the root hair with rhizobia (Journet et al. 2001; Pichon et al. 1992). This indicates the importance of the cell wall structure, infection, and nodule development. It has also been proposed that the PRP, as early nodulins, may contribute to the special morphological features of the nodule parenchyma and to the creation of an oxygen diffusion barrier (Nap and Bisseling 1990; Van de Wiel et al. 1990). About 5\% of all peptidylprolyl bonds are in cis conformation in native proteins (Mac Arhur and Thornton 1991; Stewaet et al. 1990). 
Having these data in mind, we became interested in the exploration of CyP gene expression in yellow lupine. In this study, we report the isolation and characterization of a gene coding for yellow lupine CyP. We have shown that infection of the plant by the symbiotic bacteria Bradyrhizobium sp. (lupinus) and the subsequent nodule development enhances the expression of $\mathrm{CyP}$ genes. We have also characterized the genomic locus corresponding to one of the possibly three yellow lupine $\mathrm{CyP}$ genes with promoter regions containing two motifs characteristic for nodulin genes.

\section{RESULTS}

Nucleotide sequence of yellow lupine cytosolic CyP cDNA and phylogenetic analysis of known plant CyPs.

The yellow lupine cDNA expression library from 4-day-old hypocotyls was screened for cDNA-encoding proteins able to interact with the 5S rRNA gene. Selected clones were sequenced and the expressed sequence tags data were compared with the GenBank/EMBL/DDBJ databases using the FASTA program (Pearson and Lipman 1988). One clone (cy17) revealed a high homology with other known CyP cDNAs. It is not clear whether the interaction between the 5S rRNA gene and $\mathrm{CyP}$ is specific. However, the conditions we applied for renaturation of proteins and binding with the double-stranded probe (the presence of $\mathrm{Zn}^{2+}$ in the renaturation and binding buffers) could be conductive of that kind of interaction. It is known that human recombinant $\mathrm{CyP}$ can bind and hydrolyze DNA. However, in the presence of $\mathrm{Zn}^{2+}$, it can only interact with DNA without nuclease activity (Montague et al. 1997). The cyl7 open reading frame (ORF) is 516 bp long, and its derived amino acid sequence shows a high degree of similarity to other plant CyPs. The N-terminal amino acid sequence has no targeting presequence; therefore, this protein is referred to as cytosolic CyP. The $3^{\prime}$ untranslated region contains the potential polyadenylation signal $5^{\prime}$ TATAAT 3' (nucleotides 719 through 724, relative to cDNA start). Based on the amino acid sequence, the molecular mass of the protein was estimated as $18.3 \mathrm{kDa}$. It contains the conserved tryptophan residue at position 128, which is necessary for CsA binding (Liu et al. 1991). There are 29 known sequences of plant CyP, including 27 cytosolic and 2 chloroplast forms, and all were used to construct the alignment. The multiple alignments were created by the Vector NTI program (version 5.0; InforMax; North Bethesda, MD, U.S.A.) using the Clustal W algorithm (Thompson et al. 1994). Crude similarity between all pairs of sequences was calculated first, and then the scores were used for the calculation of a "guide tree" that determined the order in which sequences were finally aligned in the multiple alignment. The plant $\mathrm{CyP}$ reveal a high rate of similarity. Most sequence divergence is seen at the carboxyl terminus, whereas the central region seems to be highly conserved. Phylogenetic tree calculation was based on a sequence-distance method by neighbor-joining algorithm (Saitou and Nei 1987) using the Phylogeny Inference Package (PHYLIP) (version 3.57c; Felsenstein 1993). The PAM matrixes of Dayhoff (1978) were used to calculate protein distances. Yellow lupine $\mathrm{CyP}$ was grouped together with cytosolic CyP from other known members of the subfamily Papilionoideae: Phaseolus vulgaris and Vicia faba (Fig. 1). In a sequence alignment with other CyP, the yellow lupine CyP, like other cytosolic forms of plant CyP, contains an insertion of seven amino acids (positions 48 to 54) relative to their animal and fungal counterparts (data not shown).

\section{Isolation and characterization}

of the yellow lupine cytosolic CyP gene.

In order to characterize $\mathrm{CyP}$ gene-promoter elements, a genomic locus of the yellow lupine CyP was isolated. Three independent clones were isolated from a genomic library of yellow lupine cv. Ventus. The nucleotide sequence of the 1,968-bp-long SalI to PstI DNA fragment containing the

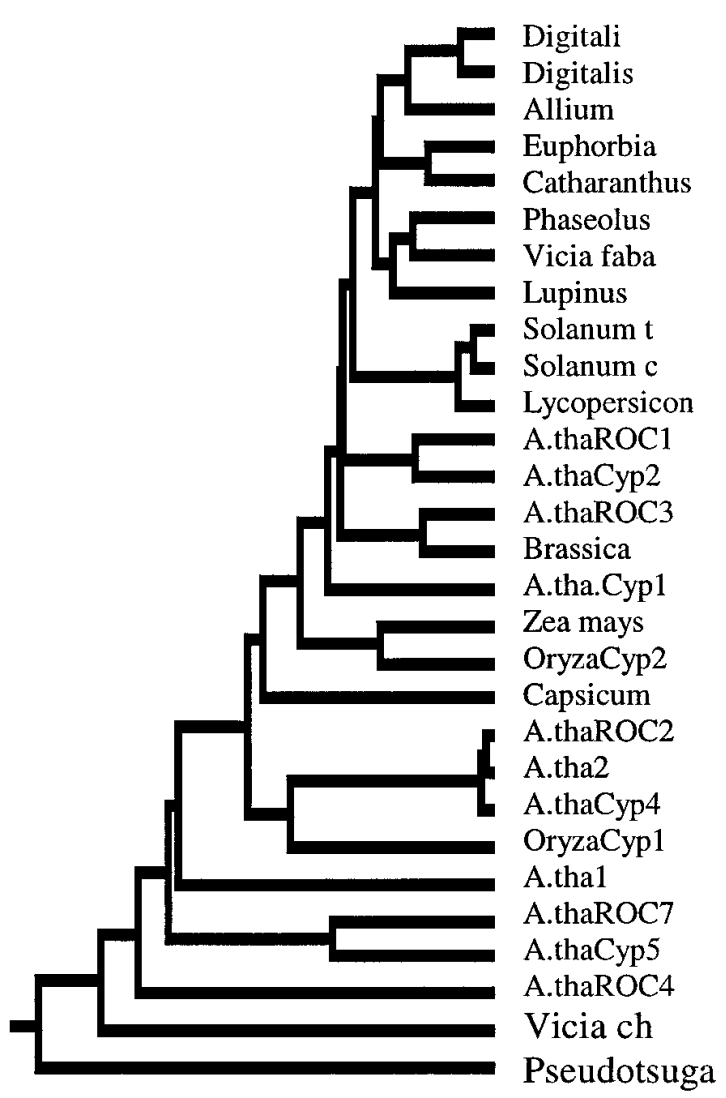

Fig. 1. Phylogenetic analysis of plant cyclophilins (CyP). The unrooted neighbor-joining tree of 29 plant $\mathrm{CyP}$ was constructed with the Phylogeny Inference Package version $3.5 \mathrm{c}$ by PAM matrix. Abbreviations and accession numbers are Digitali $=$ Digitalis lanata Y08273, Digitalis = Digitalis lanata Y08320, Allium = Allium cepa L13365, Euphorbia $=$ Euphorbia esula AF242312, Catharanthus = Catharanthus roseus $\mathrm{X} 85185$, Phaseolus $=$ Phaseolus vulgaris $\mathrm{X} 74403$, Vicia faba = Vicia faba AB012947, Lupinus = Lupinus luteus $\mathrm{Y} 16088$, Solanum $\mathrm{t}=$ Solanum tuberosum AF126551, Solanum $\mathrm{c}=$ Solanum commersonii U92087, Lycopersicon = Lycopersicon esculentum M55019, A.thaROC1 = Arabidopsis thaliana L14844, A.thaCyp2 = Arabidopsis thaliana AF020434, A.thaROC3 = Arabidopsis thaliana U40399, Brassica $=$ Brassica napus M55018, A.thaCyp1 $=$ Arabidopsis thaliana U07276, Zea mays = Zea mays M55021, OryzaCyp2 = Oryza sativa L29470, Capsicum = Capsicum annuиm AF291180, A.thaROC2 = Arabidopsis thaliana U40400, A.tha2 = Arabidopsis thaliana AL163763, A.thaCyp4 = Arabidopsis thaliana U31370, OryzaCyp1 = Oryza sativa L29471, A.tha1 = Arabidopsis thaliana X63616, A.thaROC7 = Arabidopsis thaliana AF192490, A.thaCyp5 = Arabidopsis thaliana AF020433, A.thaROC4 = Arabidopsis thaliana L14845 (chloroplast form), Vicia ch = Vicia faba L32095 (chloroplast form), and Pseudotsuga = Pseudotsuga menziesii AJ132763. 
yellow lupine CyP gene from clone cy34 was determined. The yellow lupine CyP gene, like other plant cytosolic forms (Chou and Gasser 1997), is not interrupted by intron sequences. Its 518-bp-long ORF region is $100 \%$ homologous to the previously characterized cDNA, $c y 17$. A number of sequence motifs that may regulate the expression of the gene were found at the $5^{\prime}$ part of the analyzed DNA fragment (Fig. 2). A putative TATA-box sequence is located between -60 and -55 ( $5^{\prime}$ TATAAA $\left.3^{\prime}\right)$. There is also a G-box motif spanning nucleotides -113 to -108 (5' CACGTG 3') relative to cDNA start (Shinozaki and Yamaguchi-Shinozaki 1997). The Gbox element is known to interact with transcription factors of bZIP type (Menkens et al. 1995). We have also found sequences matching the basic 5-bp heat shock element (HSE) consensus "nGAAn" (Perisic et al. 1989). Three repeats of this element are present at position -419 to -406 (5' CGAACGTTGGTTCA 3'). Two peripherally located repeats perfectly match requirements for the minimal HSF-binding motif, whereas the central repeat $\left(5^{\prime}\right.$ GTTG $\left.3^{\prime}\right)$ is 1 bp shorter. There are two elements characteristic for regulation of nodulin genes, such as a very conservative element $5^{\prime}$ AAAGAT $3^{\prime}$ that is located at -966 to -961 . This element, together with 5' CTCTT $3^{\prime}$, has been identified in several nodulin gene promoters, and these two elements appear to be necessary for their nodule-specific expression (Miao and Verma 1993; Ramlov et al. 1993). Another region characteristic for nodulin gene promoters is located between -468 and -455 ( $5^{\prime}$ TTAATATAAATAAT $\left.3^{\prime}\right)$. This element is very similar to the nodule AT-binding factor 2 motif that was found in the soybean leghemoglobin $l b c 3$ (Jensen et al. 1988) and soybean N23 promoters (Jacobsen et al. 1990). Such AT-rich elements usually appear as direct repeats, whereas there is only one present in the CyP promoter. There are also two putative auxin-responsive regions (AuxRE). The first region is very similar to the D1 AuxRE with a coupling element characterized in the soybean GH3 promoter ( $5^{\prime}$ CCTCGTGTCTC $\left.3^{\prime}\right)$ (Liu et al. 1994) that covers nucleotides -114 to $-104\left(5^{\prime}\right.$ CCACGTGTCTC $3^{\prime}$ ). The second region has a lower similarity to D1 and is located from -190 to $-185\left(5^{\prime}\right.$ TGTCCT 3'). However, in AuxRE, nucleotides TGTC are critical for binding of the auxin-responsive transcription factor (ARF) (Guilfoyle et al. 1998; Ulmasov et al. 1997). It is not clear whether these putative AuxRE elements are active. ARF binds with higher affinity to everted than to direct

-1069 ggtcgacctgcaggtcaacggatctgccccataagcttttgttgtggaatccccctcccttaattatttt -999 aatttgattcatcttattgtcttacattatataagatagagatttaactgactgaagttatattctgt

-929 tttgaacatttaataataaatccttgatattcgtaatgaaattaaaactaatgttccctcatcatgatgt

-859 gaccttttcaaaagaatcgacgccgttggataatgctcacacgctccctctgcaaattaatcaacgtaa

-789 atcgatgtccacattcatgtgtaccctccactgcataatttcacgcaacgggtatatgcataacacaaa

-719 tatataatatgtaattatacaagtgtttatacactatcaattttatccaccattcgtttaagtcgatt

-649 tattatcaatatataactttacactgattatactatatacataatatataatataatgcacagttaca

-579 cacatccacaaatattaataaaatggtataaatttatctaaattcaatatattacctaacttgtatc

-509 attttattattttcgatataaaaaataattaaaaacaaattaatataataatataccaacattaaaa

-439 ataattattttggcactaacgaacgttggttcaagtgatacatgtttaattctccttaagcaaagtctc

-369 gggtttaccctgtggatacaaaaggtatattaggagggttaagcaccacatatttaagaattttaa

-299 gactcaggcgagattactctaatacgagaatacatgtgagaaataaagaaaataagttgtgagtcataat

-229 ttaagtctatggagtgaggcataaagacgagcatatccgtgtcctcggatccgcaccactaacct.tagte

-159 aatcccatactcaaccacagttacttccttacatcaacácgcgccacgtgtctcaatccaacggccac

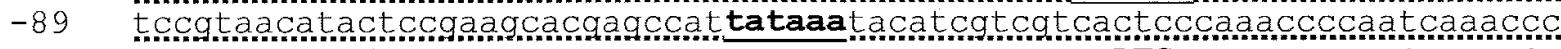

-19 tattcecttectecattecteAATCTTCAATCCCTTCCTCTCTCACCATGTCCAACCCTAAGGTTTCT TTGATATGGCCATCGCCGGCAACCCCGCCGGCCGCATCGTCATGGAGCTGTACGCCGACACCACCCCTCG 121 CACCGCCGAGAACTTCCGTGCCCTCTGCACCGGCGAGAAGGGAGTCGGCCGCAGCGGCAAGCCACTCCAT 191 TACAAGGGATCCACCTTCCACCGCGTGATCCCTAACTTCATGTGCCAGGGCGGTGATTTCACCGCCGGAA 261 ACGGTACCGGAGCCGAATCGATCTACGGAGCTAAGTTCGCTGATGAGAACTTCATCAAGAGGCACACCGG 331 TCCCGGGATCTTGTCCATGGCGAATGCTGGAGCTGGAACCAATGGATCTCAGPTCTTCATCTGTACGGAG 401 AAGACAGAGTGGCTCGATGGAAAGCACGTTGTGTTTGGTAAAGTGATTGAAGGAATGAACGTTGTGAGGG 471 ACATAGAGAAGGTTGGATCTGGATCTGGTAAAACCTCGAGGCCTGTTACTATCGCTGATTGCGGTCAACT 541 CTCTTAGATGTTGACCTCACTCTGTTCTTAATTGGTGGCTCTGATCTGTGTCGTTTTATCTTATGCGATG 611 TCGTTTTCTTTATATTTTAATGTTACTGAGTCGTCGTTTTAGGTTTTGTGATGTGTTATGGGAACACTTT 681 GTTTTTGAGTCTGTGTCGTTGTGAATGTTGATCAACATATAATGATGAGCCACCTTCAATAAAATTAGGT 751 TTATCtcataacgctttcatttatagtgatagcgttgattaacccattgtgccacaaatacaaaacgC 821 tgcagatttccaccgttgaatattcggatttataatcactctctcacggacggcatcaatatgttagcta 891 tttgttca

Fig. 2. Nucleotide sequence of yellow lupine cytosolic cyclophilin gene. The sequences upstream from the cDNA start are numbered on the left, and sequences downstream from the cDNA start are numbered on the right. The $\mathrm{cDNA}$ region $=$ capital letters, translation start ATG ant stop TAG codons $=$ capital bold letters, potential polyadenylation signal $=$ underlined bold capital letters, sequences characteristic for nodulin promoters -966 AAAGAT -961 and AT-rich region -468 TTAATATAAATAAT $-455=$ bold letters, G-box element -113 CACGTG -108 = double underlined bold italic, potential heat shock element motif -419 CGAACGTTGGTTCA $-406=$ underlined bold italic, potential auxin responsive elements -190 TGTCCT -185 and -114 CCACGTGTCTC $-104=$ bold italic, and putative TATA-box -60 TATAAA $-55=$ underlined bold. The sequence region that is $69 \%$ identical with the $5^{\prime}$ upstream region of the Phaseolus vulgaris cyclophilin gene is dotted. 
repeats. On the other hand, it is possible that the presence of a coupling element ( $5^{\prime}$ CCACGTGTCTC $3^{\prime}$ ) is sufficient for effective ARF binding (Ulmasov et al. 1995). The alignment of the $5^{\prime}$ region upstream from the yellow lupine gene has revealed the biggest similarity with the $5^{\prime}$ upstream region of the Phaseolus vulgaris $\mathrm{CyP}$ gene with $69 \%$ identity in a 212-nt overlap (data not shown). These regions contain TATA-box elements that are identical in both plants and the putative auxin-responsive element overlapping the G-box motif, but the region is one nucleotide shorter in Phaseolus vulgaris than in Lupinus luteus ( $5^{\prime}$ CCACGTGTCC 3').

A

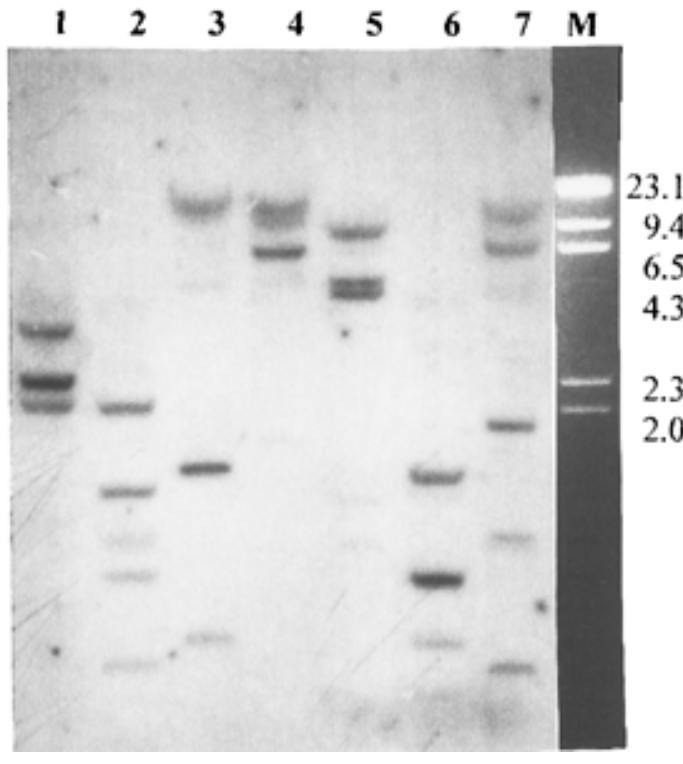

\section{Organization of genes encoding CyP.}

To determine the number of genes in the yellow lupine genome that code for CyP, Southern analyses of genomic DNA were performed. DNA samples were digested with restriction enzymes and, after electrophoresis, transferred to nylon membrane. DNA was hybridized with a $\left(\alpha-{ }^{32} \mathrm{P}\right) \mathrm{dATP}-$ labeled yellow lupine cDNA probe (probe 1) and then reprobed with the DNA fragment covering region -844 to $38 \mathrm{bp}$ upstream from the cDNA ATG codon (probe 2). In lanes containing HindIII, ClaI, SacI, ScaI, and SspI restriction digests, probe 1 hybridized with three lupine DNA fragments (Fig. 3A, lanes 1 and 3 to 6). Because the analyzed gene (Fig. 3C) and probably one

B

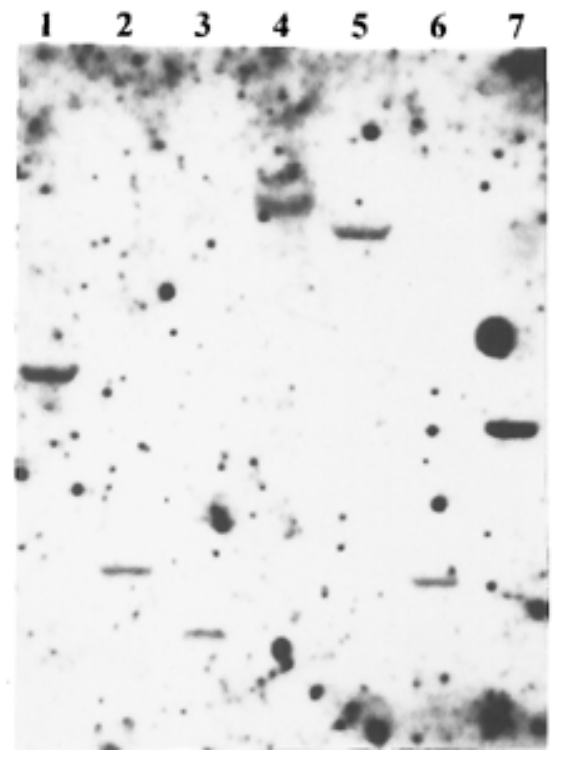

C

6.55

4.36

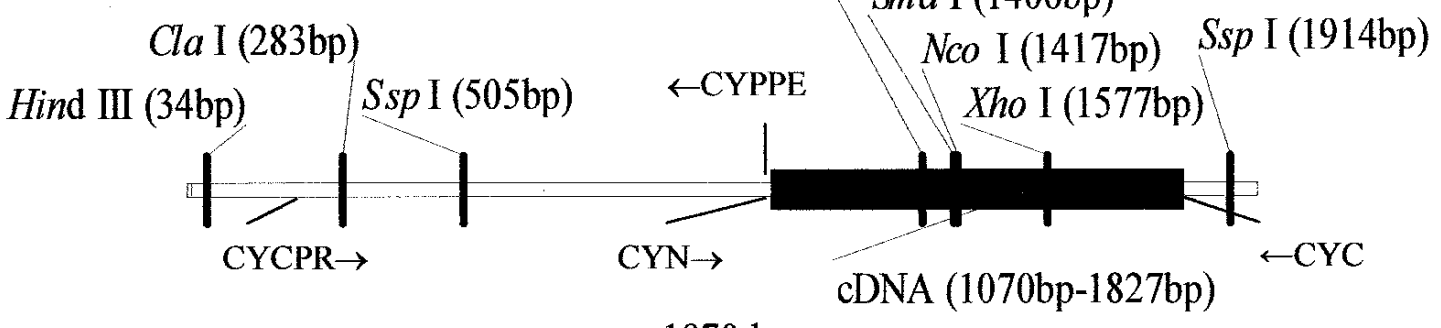

$1970 \mathrm{bp}$

Fig. 3. DNA gel blot analysis of yellow lupine genomic DNA. A and B, Each lane contains $5 \mu \mathrm{g}$ of lupine DNA digested with appropriate restriction endonuclease(s): lane 1, HindIII; lane 2, HindIII and NcoI; lane 3, ClaI; lane 4, SacI; lane 5, ScaI; lane 6, SspI; and lane 7, NdeI. Lane M is DNA size marker bacteriophage $\lambda$ digested with HindIII in kilobase pairs. DNA fragments were size-fractionated by electrophoresis in $1 \%$ agarose gel and transferred onto nylon membrane by capillary action. A, The filter-bound DNA was first hybridized with probe 1 (radiolabeled cDNA) and then B, reprobed with probe 2 (promoter region). C, Restriction map of the sequenced DNA fragment from the clone $4 \lambda$ Sal containing cytosolic cyclophilin (CyP) gene. The solid block represents the CyP cDNA region. The localization of primers used for the preparation of molecular probes is designated $\mathrm{CYN} \rightarrow$ and $\leftarrow \mathrm{CYC}$ for probe 1 and $\mathrm{CYCPR} \rightarrow$ and $\leftarrow \mathrm{CYCPE}$ for probe 2 . 
A

H $\quad 1 L \quad 2 L \quad R \quad$ C

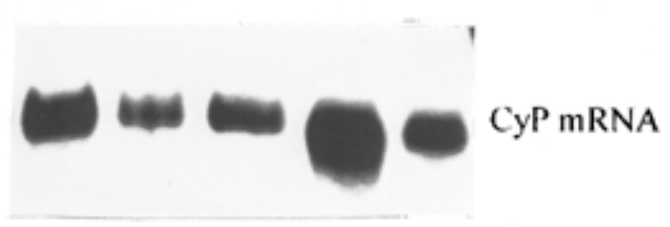

B

H $\quad$ IL $\quad 2 L \quad R \quad$ C

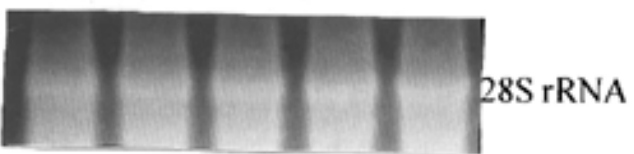

C

Hi Hn Ri Rn Ci Cn 1Li ILn 2li 2Ln

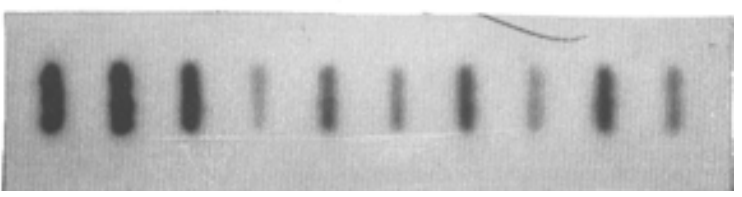

D

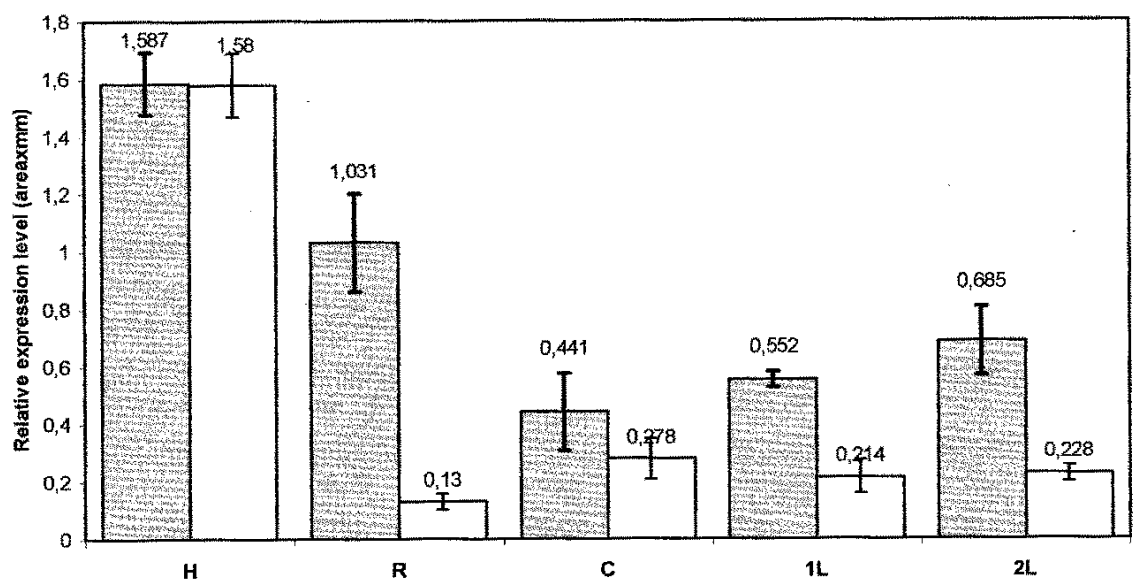

Fig. 4. Northern blot analysis. A, Northern blot analysis showing the level of lupine cyclophilin (CyP) mRNA in different organs from plants living in symbiosis with Bradyrhizobium sp. (lupinus). Hypocotyl $=\mathrm{H}$, first leaf $=1 \mathrm{~L}$, second leaf $=2 \mathrm{~L}$, root $=\mathrm{R}$, and cotyledon $=\mathrm{C}$. Total RNA samples of $5 \mu \mathrm{g}$ isolated from the indicated organs were separated on formaldehyde-agarose gel, transferred onto nylon membrane, and hybridized with the ${ }^{32} \mathrm{P}-1$ labeled lupine cyclophilin cDNA probe. B, The bottom panel shows the ethidium bromide-stained 28S rRNA as a loading control. C, Slot blot hybridization analyses showing the level of yellow lupine cytosolic CyP transcripts in different organs from uninoculated plants and plants inoculated with Bradyrhizobium sp. (lupinus). Equal amounts of slotted RNA were confirmed by spectrophotometer measurements. Slots indicated with $\mathrm{i}=$ total RNA isolated from plants inoculated with Bradyrhizobium sp. (lupinus) hypocotyl $(\mathrm{H})$, root $(\mathrm{R})$, cotyledon $(\mathrm{C})$, first leaf $(1 \mathrm{~L})$, and second leaf $(2 \mathrm{~L}) ; \mathrm{n}=$ the same organs from uninoculated plants. D, The histogram represents the mean values of three different slot blot RNA hybridization experiments. Densitometric scanning of slot blots were performed with an LKB Ultroscan XL densitometer (Amersham Pharmacia Biotech, Vienna, Austria). Dotted bars indicate plants living in symbiosis with Bradyrhizobium sp. (lupinus) and white bars indicate plants uninoculated with bacteria. Descriptions of the organs are the same as in $\mathbf{C}$. 
of the two other genes contain an internal NcoI restriction site, we can observe five hybridization signals in the lane containing DNA digested with the mixture of the restriction enzymes HindIII and NcoI (Fig. 3A, lane 2). Two or three additional faint hybridization signals were also observed in each lane. As expected for the sequenced gene from the clone $\lambda 34$ (Fig. 3C), probe 2 under high stringency conditions hybridized to a single DNA fragment in each of seven lanes (Fig. 3B). These data suggest that the yellow lupine cytosolic CyP gene is a member of a small family of related genes, three of which give strong hybridization signals with probe 1 (cDNA) and are very similar to the analyzed cytosolic CyP gene. Two genes contain an internal NcoI restriction site.

\section{Expression of $\mathrm{CyP}$ genes in yellow lupine.}

To examine the presence of mRNAs corresponding to CyP genes in different plant organs, northern and dot blot analyses were performed. Total RNA was isolated from hypocotyls (4day-old plants), cotyledons and first leaves (2-week-old plants), and second leaves and roots with and without nodules (5-weekold plants) from yellow lupine grown both axenically and in symbiosis. Although there are at least three genes similar to the analyzed cytosolic CyP in the lupine genome, after hybridization with cDNA, probe transcripts appeared as single bands in all organs tested (Fig. 4A). However, it is possible that there are several species of CyP mRNA of similar size. Cytosolic CyPs are expressed constitutively in yellow lupine. However, a significantly higher level of CyP mRNA is observed in hypocotyls than in cotyledons and leaves (Fig. 4A and C). Surprisingly, the highest level of transcripts was detected in roots carrying nodules from 5-week-old plants. In contrast, we observed the lowest level of CyP transcripts in roots from 5-weekold axenically grown plants (Fig. 4C). Densitometric analysis of hybridization signals from three different dot blot experiments demonstrated that the level of transcripts in roots from 5 -week-old axenically grown plants is nearly 12 times lower than in hypocotyls, 2 times lower than in second leaves from axenically grown plants, and 7 times lower than in roots from plants living in symbiosis with Bradyrhizobium sp. (lupinus) (Fig. 4D). Since the only difference was observed in nodules, we decided to localize CyP transcripts in yellow lupine organs, especially in nodulated roots, by in situ hybridization. The tissue ultrastructure of the nodule was classified according to Golinowski and associates (1987). Stem and root sections were hybridized with $\mathrm{CyP}$ sense and antisense RNA probes as described below. The sense probe did not yield hybridization signals above the background level (Fig. 5A and C). When sections of the stem were hybridized with the antisense RNA probe, the signal was localized mainly in the vascular cambium and phloem (Fig. 5B). In lupine root sections, the signal was localized in the vascular cambium and in the nodule tissue that surrounds the vascular bundle connecting the nodule to the root central cylinder (Fig. 5D to F). However, the strongest hybridization signal was localized in cells of the nodule meristem and its differentiating zones (Fig. 5D and E). There was no hybridization signal in the differentiated zone (Fig. 5D). Results obtained from the in situ hybridization experiments are in agreement with those obtained from northern and dot blot hybridizations. $\mathrm{CyP}$ transcripts were observed mainly in developing tissue, such as the cambium, and the highest level was observed in the nodule meristem zone.

\section{DISCUSSION}

We report the isolation and molecular characterization of a yellow lupine cytosolic CyP gene. Plant CyPs reveal high rates of similarity. Since Chou and Gasser (1997) published their phylogenetic analysis of eukaryotic and prokaryotic CyPs (108 sequences), 11 new plant CyP sequences have appeared in the GenBank/EMBL/DDBJ and Swiss-Prot databases. In the unrooted neighbor-joining tree, the yellow lupine cytosolic CyP is grouped with cytosolic CyP forms from the subfamily Papilionoideae (Fig. 1). However, the chloroplast form of CyP from Vicia faba is placed at one extreme of this tree together with ROC4 (a chloroplast form of $\mathrm{CyP}$ from Arabidopsis thaliana). This confirms the previous suggestion by Chou and Gasser (1997) of early divergence of chloroplast CyP since, in the neighbor-joining tree prepared by them, these two CyPs form an independent clade placed between high molecular mass $\mathrm{CyP}$ and those from endoplasmic reticulum. There are at least three genes present in the yellow lupine genome-encoding CyP related to the analyzed cytosolic form (Fig. 3A and B). Genes encoding cytosolic CyP are known to be constitutively expressed, but higher CyP mRNA levels were observed in young developing tissues and organs. In yellow lupine, the highest level of CyP transcripts was observed in hypocotyls from 4-day-old seedlings of both uninoculated plants and plants inoculated with Bradyrhizobium sp. (lupinus) (Fig. 4). The elevated level of $\mathrm{CyP}$ gene expression observed in hypocotyls is probably related to an intensive enzymatic activity and chaperone function of the $\mathrm{CyP}$ in young developing tissues. This is consistent with observations reported for other plant species (Marivet et al. 1994, 1995) in which CyP genes were found to be highly expressed in young leaves, floral buds, and other young and developing organs. We have unexpectedly found that the level of Cyp mRNAs increased dramatically in nodulated roots (Fig. 4A and C) compared with uninfected roots. In order to clarify this phenomenon, in situ hybridization was performed on stem and root sections taken from plants inoculated with Bradyrhizobium sp. (lupinus) (Fig. 5). In stem sections, the hybridization signal was localized mainly in the vascular cambium (which is a meristematic tissue) and phloem. In root sections, transcripts were detected at a very high level in the nodule meristem and in differentiating zones. Hybridization signals were also detectable in the nodule vascular bundle. As lupine nodules are characterized by an indeterminated type of growth, peripherally located meristems are continuously active during plant life (Goormachtig et al. 1997). At the beginning of nodule development, the meristem zone occupies much more nodule area than in adult nodules, which have enlarged fixation zones. The distribution of in situ hybridization signals corresponding to the presence of Cyp transcripts correlates with the localization and dimensions of the meristem zone during nodule development (Fig. 5D and E). As a result of Bradyrhizobium sp. (lupinus) infection, many PRP and HRGP are intensively expressed (Cassab 1986; Sherrier and VandenBosch 1994). It is proposed that PRP and HRGP play an important role in nodule morphogenesis. Some of them are expressed in the nodule meristem (Wilson et al. 1994) and in the paren- 
chyma (Bonilla et al. 1997), modifying cell wall structure in this tissue forming a specific barrier for $\mathrm{O}_{2}$ diffusion. PRP and Pro-, Thr-, and Gly-rich proteins (PTGRP) were also found in the cell wall of xylem elements (Harrak et al. 1999; Wyatt et al. 1992; Ye et al. 1991). Our study has shown that the lupine CyP genes are expressed mainly in young developing tissues, particularly greater amounts of transcripts are detected in tis- sue in which high levels of PRP and HRGP are synthesized. CyP acting as either PPIases or chaperones, or both, might be necessary for proper folding of PRP, PTGRP, and HRGP. After bacterial inoculation, CyP gene expression was enhanced in almost all tested organs in comparison with axenically grown plants (Fig. 4C and D). The exception was in hypocotyls, where CyP transcript levels were nearly the same. To bet-

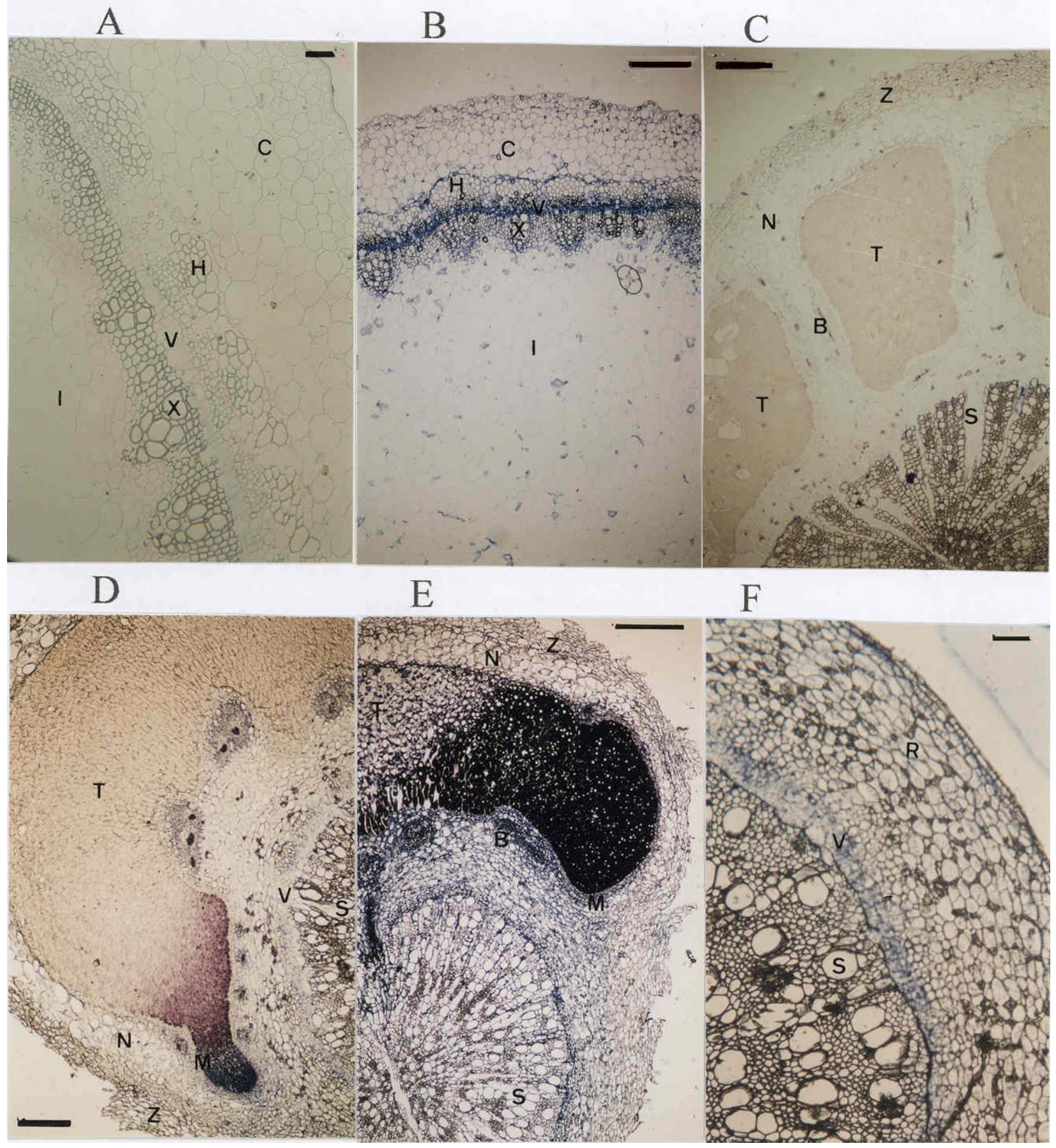

Fig. 5. Localization of a cytosolic cyclophilin (CyP) mRNA in yellow lupine stems and nodulated roots by in situ hybridization. Cross sections of $\mathbf{A}$, stem and $\mathbf{C}$, nodulated root were hybridized with a biotin-16-uridine triphosphate-labeled sense cytosolic CyP probe. B, Cross sections of stem and $\mathbf{D}$ to F, nodulated root were hybridized with a biotin-16-UTP-labeled antisense cytosolic CyP probe. F, Cross section of the nodulated root region across to the nodule. $\mathrm{M}=$ nodule meristem, $\mathrm{C}=$ cortex, $\mathrm{H}=$ phloem, $\mathrm{B}=$ vascular bundle, $\mathrm{V}=$ vascular cambium, $\mathrm{X}=\mathrm{xylem}, \mathrm{I}=$ pith parenchyma, $\mathrm{N}=$ nodule cortex, $\mathrm{S}=$ root stela, $\mathrm{T}=$ bacteroid tissue, $\mathrm{R}=$ root cortex, and $\mathrm{Z}=$ protective tissue. $\mathbf{A}$ and $\mathbf{F}$, Scale bars $=100 \mu \mathrm{m} ;$ and $\mathbf{B}$ to $\mathbf{E}, \mathrm{Scale}$ bars $=500 \mu \mathrm{m}$. 
ter understand the regulation of $\mathrm{CyP}$ gene expression, a genomic clone was isolated and characterized. Analysis of the CyP gene $5^{\prime}$ flanking region revealed the presence of TATAbox, G-box, and auxin-responsible consensus sequence. It is interesting that -114 AuxRe -104 overlaps the -113 G-box -108 element. It has been proposed that the G-box motif serves as a binding site for a transcriptional factor, and sequences flanking the G-box core motif (CACGTG) determine its transcriptional activity (Liu et al. 1997; Ulmasov et al. 1995). The G-box element has been identified in several promoters regulated by different stimuli (Donald and Cashmore 1990; Mundy et al. 1990). It is possible that in the absence or at low levels of the auxin, the TGTCTC element acts to repress the activity of the adjacent G-box and, when auxin was added, the AuxRe is derepressed and upregulated. However, these G-box and AuxRE elements have not been tested for functionality, and their direct role in the CyP gene regulation remains to be clarified. We have found almost the same motif, except for being one nucleotide shorter $\left(5^{\prime}\right.$ CCACGTGTCC $3^{\prime}$ ), in the $5^{\prime}$ upstream 212-nt-long region of the Phaseolus vulgaris CyP gene. The alignment of these two sequences revealed $69 \%$ identity in the 212-nt overlap. This region contains a TATA-box motif that is identical in both plants. We also found two sequence elements characteristic for the regulation of nodulin gene expression, a highly conserved $5^{\prime}$ AAAGAT $3^{\prime}$ motif, and an AT-rich region. Whether these motifs affect expression of the yellow lupine CyP gene remains unclear. In spite of the original definition of nodulins, which says their genes are expressed only in nodules, it is now known that most nodulin genes are also expressed in other tissues (Brewin 1991; Franssen et al. 1992; Hadri and Bisseling 1998). The intensification of CyP gene expression in plants inoculated with symbiotic bacteria might suggest a systemic response. Although members of the genus Bradyrhizobium are a natural yellow lupine symbiotic bacteria, molecular response spreads in a plant after infection and during nodule development, strengthening the expression of some stress-related proteins, including CyP. In Medicago truncatula, some nodulation-specific genes encode proteins that are structurally related to those associated with defense response (Gamas et al. 1998). Genes encoding these proteins are not induced by bacterial pathogens, and their products are called nodulation-specific defense proteins. Some nodulin genes are also expressed during mycorrhizal development (Journet et al. 2001; Udvardi 2001). CyPs are postulated to be involved in plant defense mechanisms in response to cold stress, heat shock, chemical treatment, and wounding (Marivet et al. 1994, 1995). Expression of yellow lupine $\mathrm{CyP}$ genes is modulated by cold stress and heat shock (data not shown), but the response is nonsignificant in comparison to the response observed in other plants, e.g., chloroplast CyP from the fava bean (Hennig et al. 1998). The promoter region of the yellow lupine cytosolic CyP gene contains sequence elements that match eukaryotic HSE consensus (nGAAn), which is the binding site for HSF. The best efficiency of HSF binding is observed when three units of HSE are repeated. Since the middle segment of the three minimal HSE repeats found in the CyP gene is shorter than the two flanking repeats, 5' CGAACGTTGGTTCA 3', it may be responsible for the weak answer of yellow lupine cytosolic CyP to temperature shock.

\section{MATERIALS AND METHODS}

\section{Plant material and growth conditions.}

Yellow lupine (Lupinus luteus cv. Ventus) seeds were obtained from T. Nijaki (Plant Breeding Station, Wiatrowo, Poland). Prior to germination, seeds were sterilized for $15 \mathrm{~min}$ in $5 \%$ hydrogen peroxide and rinsed several times with distilled water. Inoculation with Bradyrhizobium sp. (lupinus) strain USDA 3045 was performed on the second day of germination. While sowing the seeds into pots, liquid culture of Bradyrhizobium sp. (lupinus) (cultivated 2 days in a yeast mannitol broth medium of $0.05 \% \quad \mathrm{KH}_{2} \mathrm{PO}_{4}, 0.02 \% \quad \mathrm{MgSO}_{4}, 0.01 \%$ $\mathrm{NaCl}, 1 \%$ mannitol, and $0.05 \%$ yeast extract at $28^{\circ} \mathrm{C}$ ) was applied at the rate of $2 \mathrm{ml}$ per seed. Inoculated and uninoculated plants were grown in the greenhouse simultaneously. Plants inoculated with Bradyrhizobium sp. (lupinus) were supplied with modified nitrogen-free growth medium (Dilworth 1980), and axenically grown plants were supplied with the same medium supplemented with $8.5 \mathrm{mM} \mathrm{Ca}\left(\mathrm{NO}_{3}\right)_{2}$ and $1.6 \mu \mathrm{M}$ $\left(\mathrm{NH}_{4}\right)_{6} \mathrm{MoO}_{7} \mathrm{O}_{24}$. Plant organs harvested for RNA isolation were hypocotyls (4-day-old plants), cotyledons and primary leaves (2-week-old plants), and secondary leaves and roots (5week-old plants).

\section{Construction and screening \\ of yellow lupine cDNA library.}

Total RNA was isolated as described by Ainsworth and associates (1991) from hypocotyls of 4-day-old seedlings grown in the dark. Poly(A)-RNA was purified by oligo(dT)-cellulose chromatography according to the manufacturer's recommendations (Amersham Pharmacia Biotech, Vienna, Austria). The cDNA was synthesized using the Zap cDNA synthesis kit (Stratagene, La Jolla, CA, U.S.A.). The cDNAs were ligated unidirectionally into the EcoRI-XhoI sites of the $\lambda$ Uni-ZAP $\mathrm{XR}$ cloning vector. The library was screened for proteins that interact with the 5S rRNA gene. The probe consisted of three tandemly repeated units containing 5S rRNA gene (Nuc et al. 1993). Since the prepared DNA fragment was cloned into pGEM-5Zf plasmid (pG63), the double-stranded probe was generated by a polymerase chain reaction (PCR) using universal forward and reverse M13 sequencing primers with $\left[\alpha-{ }^{32} \mathrm{P}\right] \mathrm{dATP}$. Duralose filters (Stratagene) were impregnated with $10 \mathrm{mM}$ isopropyl-thio-galactopyranoside for protein synthesis induction. Proteins bound to the filters were denatured in buffer D (20 mM $N$-2-hydroxyethylpiperazine- $N$-2-ethanesulfonic acid$\mathrm{KOH}, \mathrm{pH} 7.0 ; 10 \mathrm{mM} \mathrm{ZnCl}_{2} ; 3 \mathrm{mM} \mathrm{MgCl}_{2}$; and $40 \mathrm{mM} \mathrm{KCl}$ ) supplemented with $6 \mathrm{M}$ guanidinium hydrochloride and $1 \mathrm{mM}$ of DDT for $10 \mathrm{~min}$ at $4^{\circ} \mathrm{C}$. Proteins were renatured by stepwise dilution in buffer D every $5 \mathrm{~min}$. After protein renaturation, filters were treated with buffer D supplemented with $5 \%$ nonfat milk, $10 \mu \mathrm{g}$ of denatured salmon sperm DNA per ml, and $1 \mathrm{mM}$ dithiothreitol for $1 \mathrm{~h}$. The binding reaction was carried out for $4 \mathrm{~h}$ in buffer $\mathrm{D}$ supplemented with the ${ }^{32} \mathrm{P}$-labeled double-stranded probe at $4{ }^{\circ} \mathrm{C}$. After binding, the filters were washed for $30 \mathrm{~min}$ in buffer D. Filters were autoradiographed by night at $-80^{\circ} \mathrm{C}$ with an intensifying screen. Plasmid subclones were made from the isolated phages by coinfection with the helper phage ExAssist (Stratagene), according to the manufacturer's instructions. After in vivo excision, selected clones were successively sequenced using the Sanger dideoxy chain termination method (Sanger 1981). Cycle- 
sequencing reactions were performed using the thermo sequenase fluorescent-labeled primer sequencing kit (Amersham Pharmacia Biotech). Sequencing reactions were loaded onto a $5.5 \%$ denaturing polyacrylamide gel and analyzed using the ALFexpress DNA sequencing system (Amersham Pharmacia Biotech). Subcloning was performed using standard techniques (Sambrook et al. 1989). The nucleotide sequence data obtained were compared with GenBank/EMBL/DDBJ databases using the FASTA program (Pearson and Lipman 1988).

\section{RNA isolation and northern hybridization.}

Total RNA was isolated from plant material by phenol extraction and $\mathrm{LiCl}$ precipitation as described by Ainsworth and associates (1991). A molecular probe for northern and slot blots was prepared with $\left[\alpha-{ }^{32} \mathrm{P}\right] \mathrm{dATP}$ by PCR reaction using cDNA for $c y 17$ cloned in pBluescript $\mathrm{SK}^{(-)}$as a template and specific oligodeoxyribonucleotides CYN (5' CCCTTCCTCTCTCACCATGTCC 3') homologous to nucleotides 14 through 25 and CYC (5'CGACACAGATCAGAGCCACC 3') complementary to nucleotides 575 through 594 (Fig. 3). RNA samples $(5 \mu \mathrm{g})$ were denatured in formamide/formaldehyde by heating at $65^{\circ} \mathrm{C}$ for $5 \mathrm{~min}$ and fractionated by electrophoresis in $1.2 \%$ agarose gel containing formaldehyde (Sambrook et al. 1989). The equal amounts of RNA were confirmed by staining the gel with ethidium bromide (Fig. 4B). After electrophoresis, RNA was transferred onto Hybond $\mathrm{N}^{+}$membrane (Amersham Pharmacia Biotech) as recommended by the manufacturer. For slot blot analysis, denatured RNA samples were applied to the wells of a MINIFOLD II Slot-Blotter (Schleicher \& Schuell, Inc., Dassel, Germany) and transferred under vacuum onto Hybond $\mathrm{N}^{+}$membrane. Blots were airdried, and RNA was fixed to the membrane and incubated at $80^{\circ} \mathrm{C}$ for $90 \mathrm{~min}$. Hybridization was performed at $55^{\circ} \mathrm{C}$ in $5 \times$ SSPE $\left(1 \times \mathrm{SSPE}\right.$ is $0.18 \mathrm{M} \mathrm{NaCl}, 10 \mathrm{mM} \mathrm{NaPO}_{4}$, and $1 \mathrm{mM}$ EDTA [pH 7.7]) and $1 \%$ sodium dodecyl sulfate (SDS) for 24 h. The final washes were performed in $0.5 \times \mathrm{SSPE}$ at $60^{\circ} \mathrm{C}$. Densitometric scanning of slot blots and northern blots was performed with an LKB Ultroscan XL densitometer (Amersham Pharmacia Biotech, Vienna, Austria).

\section{In situ localization of yellow lupine $\mathrm{CyP}$ transcripts.}

Nodulated roots and stems were harvested from 8-week-old plants. Tissue fixation, section pretreatment, and in situ hybridizations were performed as described by Dixon and associates (1995) with some modifications. Plant strips $(3 \mathrm{~mm}$ thick) were fixed in a solution containing $4 \%$ formaldehyde in phosphate-buffered saline (PBS), $\mathrm{pH} 7.0$, for $3 \mathrm{~h}$ at room temperature with one change of the buffer. After washing twice with $1 \times$ PBS, the fixed tissue samples were dehydrated in an ethanol dilution series, infiltrated in xylene, and embedded in Paraplast Plus (Sigma-Aldrich, St. Louis, MO, U.S.A.). After sectioning with a microtome, $10-\mu \mathrm{m}$ sections were mounted on slides. Sense and antisense probes were generated by transcription with T3 or T7 RNA polymerase from linearized plasmid containing lupine $\mathrm{CyP}$ cyl7 cDNA insert with biotin-16UTP triphosphate according to the manufacturer's instructions (Roche Diagnostics, Mannheim, Germany). Just before hybridization, paraffin was removed by xylene treatment. After hybridization, the tissue sections were rehydrated and acetylated in $0.4 \%$ acetic anhydride. Probe penetration was increased by the treatment of sections with $1 \mu \mathrm{g}$ of proteinase $\mathrm{K}$ per $\mathrm{ml}$ for $10 \mathrm{~min}$. The hybridization was performed in buffer $\mathrm{H}$ (4× SSC $[1 \times \mathrm{SSC}$ is $0.15 \mathrm{M} \mathrm{NaCl}$ plus $0.015 \mathrm{M}$ sodium citrate], $50 \%$ formamide, $1 \times$ Denhardt's solution, and $0.3 \mathrm{mg}$ of tRNA per ml) at $42^{\circ} \mathrm{C}$ for $24 \mathrm{~h}$ with $40 \mathrm{ng}$ of biotin-labeled RNA probe per ml. After incubation with AP-conjugate and color development using 5-bromo-4-chloro-3-indolyl phosphate and nitro-blue tetrazolium substrates, sections were photographed using an Olympus BX 40 microscope (Olympus, Melville, NY, U.S.A.).

\section{Genomic library screening.}

The Lupinus luteus cv. Ventus genomic library, cloned in a $\lambda$ EMBL 3 vector, was a generous gift from A. B. Legocki (Institute of Bioorganic Chemistry Polish Academy of Sciences, Poznań, Poland). About $8 \times 10^{5}$ recombinant phages of this library were screened with $\left[\alpha-{ }^{32} \mathrm{P}\right] \mathrm{dATP}-$ labeled yellow lupine cDNA (cy17). DNA from bacteriophage plaques were transferred to Hybond $\mathrm{N}^{+}$membrane, denatured, and fixed according to a standard method (Sambrook et al. 1989). Hybridization was performed at $55^{\circ} \mathrm{C}$ in $5 \times \mathrm{SSPE}$ and $0.5 \%$ SDS for $24 \mathrm{~h}$. The final washes were performed in $0.5 \times \mathrm{SSPE}$ at $60^{\circ} \mathrm{C}$. Three individual plaques, 12, 21, and 34, were isolated, and the phage DNA was purified. One clone (cy34) was selected, a SalI restriction DNA fragment of about $4 \mathrm{~kb}$ was recloned to the pUC18 plasmid ( $4 \lambda \mathrm{Sal})$, and the nucleotide sequence of the 1,968-bp-long DNA fragment with the lupine CyP gene was analyzed. Sequencing reactions were performed as described above.

\section{Isolation of nuclear DNA from Lupinus luteus seedlings and Southern hybridization.}

DNA was isolated from 3-day-old seedlings. Nuclei were isolated by the Jofuku and Goldberg method (Jofuku et al. 1988). Lysis of nuclear fraction and DNA purification was performed as described previously (Nuc et al. 1997). Nuclear DNA $(5 \mu \mathrm{g})$ was digested by appropriate restriction enzymes and separated by electrophoresis in $1 \%$ agarose gel. Southern blot analyses were performed using standard techniques (Sambrook et al. 1989). Molecular probe 1 was prepared as described for RNA hybridizations. Probe 2 was prepared with $\left[\alpha-{ }^{32} \mathrm{P}\right] \mathrm{dATP}$ by PCR reaction using $4 \lambda \mathrm{Sal}$ plasmid as a template and specific oligodeoxyribonucleotides CYCPR (5' AATCGACGCCGTTGGATAATGCTC $3^{\prime}$ ) homologous to nucleotides -844 through -820 and CYCPE complementary to nucleotides 14 through 38 (5' GTTGGACATGGTGAGAGAGGAAGGG 3') (Fig. 3). Filters were washed in $3 \times$ SSPE and $0.1 \%$ SDS at $65^{\circ} \mathrm{C}$ for several hours. Hybridization was performed at $55^{\circ} \mathrm{C}$ in $5 \times$ SSPE, $0.5 \%$ SDS, and $1 \times$ Denhardt's solution for $24 \mathrm{~h}$. The final washes were performed in $0.5 \times \mathrm{SSPE}$ at $60^{\circ} \mathrm{C}$.

\section{Phylogenetic analyses.}

GenBank/EMBL/DDBJ and Swiss-Prot databases were searched using the FASTA program (Pearson and Lipman 1988) for any sequences with similarity to yellow lupine CyP. Amino acid sequences of 29 plant CyPs were used for alignments and phylogenetic tree construction. A multiple alignment was created by the Vector NTI program (version 5.0) using the Clustal W algorithm (Thompson et al. 1994), and the phylogenetic tree calculation was prepared with the PHYLIP (version 3.57c; Felsenstein 1993) based on a sequence-distance method using the neighbor-joining algorithm (Saitou 
and Nei 1987) with the PAM matrixes of Dayhoff (1978) for calculation of protein distances.

\section{ACKNOWLEDGMENTS}

We thank A. B. Legocki for providing the genomic library, E. Laskowska for preparing tissue slides, and M. Guranowska for assistance with microscopy. We are grateful to C. J. Mądrzak, M. Sikorski, and K. Pudekko for useful practical advice. We thank J. Pawełkiewicz, A. Guranowski, and K. Gayler for critical discussion and comments on the manuscript. This work was supported by the State Committee for Scientific Research (KBN), grants 0226/PO4/98/14, 183/R/81/W, and UAMAR PV-11/2

\section{LITERATURE CITED}

Ainsworth, C., Beynon, J., and Buchanan-Wollaston, V. 1991. Techniques in Plant Molecular Biology: The Practical Manual. Wye College, Ashford, Kent, U.K.

Arsenijević-Maksimović, I., Broughton, W. J., and Krause, A. 1997. Rhizobia modulate root-hair-specific expression of extensin genes. Mol. Plant-Microbe Interact. 10:95-101.

Baker, E. K., Colley, N. J., and Zuker, C. S. 1994. The cyclophilin homolog NinaA functions as a chaperone, forming a stable complex in vivo with its protein target rhodopsin. EMBO (Eur. Mol. Biol. Organ.) J. 13:4886-4895.

Bonilla, I., Mergold-Villasenor, C., Campos, M. E., Sanchez, N., Perez, H., Lopez, L., Castrejon, L., Sanchez, F., and Cassab, G. I. 1997. The aberrant cell walls of boron-deficient bean root nodules have no covalently bound hydroxyproline/proline-rich proteins. Plant Physiol. 115:1329-1340.

Brewin, N. J. 1991. Development of the legume root nodule. Annu. Rev. Cell Biol. 7:191-226.

Cassab, G. I. 1986. Arabinogalactan proteins during the development of soybean root nodules. Planta 168:441-446.

Chou, I. T., and Gasser, C. S. 1997. Characterization of the cyclophilin gene family of Arabidopsis thaliana and phylogenetic analysis of known cyclophilin proteins. Plant Mol. Biol. 35:873-892.

Dayhoff, M. O. 1978. Survey of new data and computer methods of analysis. Pages 2-8 in: Atlas of Protein Sequence and Structure. Vol. 5. National Biomedical Research Fundation. Silver Spring, MD, U.S.A.

de Bruijn, F. J., and Schell, J. 1992. Regulation of plant genes specifically induced in developing and mature nitrogen-fixing nodules: Cisacting elements and trans-acting factors. Pages 241-258 in: Control of Plant Gene Expression. D. P. S. Verma, ed. CRC Press, Boca Raton, FL, U.S.A.

Deng, W., Chen, L., Wood, D. W., Metcalfe, T., Liang, X., Gordon, M. P., Comai, L., and Nester, E. W. 1998. Agrobacterium VirD2 protein interacts with plant host cyclophilin. Proc. Natl. Acad. Sci. U.S.A. 95:7040-7045.

Dilworth, M. J. 1980. Leghemoglobins. Methods Enzymol. 69:812-823.

Dixon, D. C., Cutt, J. R., and Klessig, D. F. 1995. In situ hybridization for the detection of RNA in plant tissues. Pages 111-140 in: Methods in Plant Molecular Biology, CSHL Press, New York.

Donald, R. G. K., and Cashmore, A. R. 1990. Mutation of either G-box or I-box sequences profoundly affects expression from the Arabidopsis rbcS-1A promoter. EMBO (Eur. Mol. Biol. Organ.) J. 9:17171726.

Felsenstein, J. 1993. PHYLIP (Phylogeny Inference Package) version 3.5c. Distributed by the author. Department of Genetics, University of Washington, Seattle, WA, U.S.A.

Fisher, G., Wittmann-Liebold, B., Lang, K., Kiefhaber, T., and Schmid, F. X. 1989. Cyclophilin and the peptidyl-prolyl cis-trans isomerase are probably identical proteins. Nature 337:476-478.

Franke, E. K., Yuan, H. E. H., and Luban, J. 1994. Specific incorporation of cyclophilin A into HIV-1 virions. Nature 372:359-362.

Franssen, H. J., Nap, J. P., and Bisseling, T. 1992. Nodulins in root nodule development. Pages 598-624 in: Biological Nitrogen Fixation. Chapman \& Hall, New York.

Freskgard, P. O., Bergenhem, N., Jonsson, B. H., Svensson, M., and Carlsson, U. 1992. Isomerase and chaperone activity of prolyl isomerase in the folding of carbonic anhydrase. Science 258:466-468.
Fulgosi, H., Vener, A. V., Altschmied, L., Herrmann, R. G., and Andersson, B. 1998. A novel multi-functional chloroplast protein: Identification of a 40-kDa immunophilin-like protein located in the thylakoid lumen. EMBO (Eur. Mol. Biol. Organ.) J. 17:1577-1587.

Galat, A. 1993. Peptidylproline cis-trans isomerases: Immunophilins. Eur. J. Biochem. 216:689-707.

Gamas, P., de Billy, F., and Truchet, G. 1998. Symbiosis-specific expression of two Medicago trucatula nodulin genes, MtN1 and MtN13, encoding products homoloqous to plant defense proteins. Mol. PlantMicrobe Interact. 11:393-403.

Golinowski, W., Kopicińsk, J., and Borucki, W. 1987. The morphogenesis of lupine root nodules during infection by Rhizobium lupini. Acta Soc. Bot. Pol. 4:687-703.

Goormachtig, S., Alves-Ferreira, M., Van Montagu, M., Engler, G., and Holster, M. 1997. Expression of cell cycle genes during Sesbania rostrata stem nodule development. Mol. Plant-Microbe Interact. 10:316325.

Guilfoyle, T. J., Ulmasov, T., and Hagen, G. 1998. The ARF family of transcription factors and their role in plant hormone responsive transcription. Cell Mol. Life Sci. 54:619-627.

Hadri, A. E., and Bisseling, T. 1998. Responses of the plant to Nod factors. Pages 403-416 in: The Rhizobiaceae: Molecular Biology of Model Plant-Associated Bacteria. H. P. Spaink, A. Kondorosi, and P. J. J. Hooykaas, eds. Kluwer Academic Publishers, Dordrecht, The Netherlands.

Handschumacher, R., Harding, M., Rice, J., and Drugge, R. 1984. Cyclophilin: A specific cytosolic binding protein for cyclosporin A. Science 226:544-546.

Harrak, H., Chamberland, H., Plante, M., Bellemare, G., Lafontaine, J. G., and Tabaeizadeh, Z. 1999. A proline-, threonine-, and glycine-rich protein down-regulated by drought is localized in the cell wall of xylem elements. Plant Physiol. 121:557-564.

Hennig, L., Christner, C., Kipping, M., Schelbert, B., Rucknagel, K. P., Grabley, S., Kullertz, G., and Fischer, G. 1998. Selective inactivation of parvulin-like peptidyl-prolyl cis/trans isomerases by juglone. Biochemistry 28:5953-5960.

Jacobsen, K., Lauren, N. B., Jensen, E. O., Marcker, A., Poulsen, C., and Marcker, K. A. 1990. HMG I-like proteins from leaf and nodule nuclei interact with different AT motifs in soybean nodulin promoters. Plant Cell 2:85-95.

Jensen, E. O., Marcker, K. A., Schell, J., and de Bruijn, F. J. 1988. Interaction of a nodule specific trans-acting factor with distinct DNA elements in the soybean leghemoglobin lbc3 $5^{\prime}$ upstream region. EMBO (Eur. Mol. Biol. Organ.) J. 7:1265-1271.

Jofuku, K. D., and Goldberg, R. B. 1988. Analysis of plant gene structure w. Pages 37-66 in: Plant Molecular Biology: A Practical Approach. C. W. Shaw, ed. IRL Press, Oxford.

Journet, E.-P., El-Gachtouli, N., Vernoud, V., de Billy, F., Pichon, M., Dedieu, A., Arnould, C., Morandi, D., Barker, D. G., and GianinazziPearson, V. 2001. Medicago truncatula ENOD11: A novel RPRPencoding early nodulin gene expressed during mycorrhization in arbuscule-containing cells. Mol. Plant-Microbe Interact. 14:737-748.

Keen, N., Gelvin, S. B., and Long, S., 1999. Summary of IS-MPMI meeting, July 1999, Amsterdam. Mol. Plant-Microbe Interact. 12:835838.

Liu, J., Chen, C. M., and Walsh, C. T. 1991. Human and Escherichia coli cyclophilins sensitivity to inhibition by the immunosuppressant cyclosporin A correlates with a specific tryptophan residue. Biochemistry $30: 2306-2310$.

Liu, Z.-B, Ulmasov, T., Shi, X., Hagen, G., and Guilfoyle, T. J. 1994. The soybean $G H 3$ promoter contains multiple auxin-inducible elements. Plant Cell 6:645-657.

Liu, Z.-B., Hagen, G., and Guilfoyle, T. J. 1997. A G-Box-binding protein from soybean binds to the E1 auxin-response element in the soybean SH3 promoter and contains a proline-rich repression domain. Plant Physiol. 115:397-407.

Luan, S., Lane, W. S., and Schreiber, S. L. 1994. pCyP B: A chloroplastlocalized, heat shock-responsive cyclophilin from fava bean. Plant Cell 6:885-892

Luban, J. 1996. Absconding with the chaperone: Essential cyclophilinGag interaction in HIV-1 virions. Cell 87:1157-1159.

Luban, J., Bossolt, K. L., Franke, E. K., Kalpana, G. V., and Goff, S. P. 1993. Human immunodeficiency virus type $1 \mathrm{Gag}$ protein binds to cyclophilins A and B. Cell 73:1067-1078. 
Mac Arhur, M. W., and Thornton, J. M. 1991. Influence of proline residues on protein conformation. J. Mol. Biol. 218:397-412.

Marivet, J., Margis-Pinheiro, M., Frendo, P., and Burkard, G. 1994. Bean cyclophilin gene expression during plant development and stress conditions. Plant Mol. Biol. 26:1181-1189.

Marivet, J., Frendo, P., and Burkard, G. 1995. DNA sequence analysis of a cyclophilin gene from maize: Developmental expression and regulation by salicylic acid. Mol. Gen. Genet. 247:222-228.

Matouschek, A., Rospert, S., Schmid, K., Glick, B. S., and Schatz, G. 1995. Cyclophilin catalyzes protein folding in yeast mitochondria. Proc. Natl. Acad. Sci. U.S.A. 92:6319-6323.

Menkens, A. E., Schindler, U., and Cashmore A. R. 1995. The G-box: A ubiquitous regulatory DNA element in plants bound by the GBF family of bZIP proteins. Trends Biochem. Sci. 20:506-510.

Miao, G. H., and Verma, D. P. S. 1993. Soybean nodulin-26 gene encoding a channel protein is expressed only in the infected cells of nodules and is regulated differently in roots of homologous and heterologous plants. Plant Cell 5:781-784.

Montague, J. W., Gaido, M. L., Frye, C., and Cidlowski, J. A. 1994. A calcium-dependent nuclease from apoptotic rat thymocytes is homologous with cyclophilin. J. Biol. Chem. 269:18877-18880.

Montague, J. W., Hughes, F. M., and Cidlowski, J. A. 1997. Native recombinant cyclophilins A, B, and C degrade DNA independently of peptidylprolyl cis-trans-isomerase activity. Potential roles of cyclophilins in apoptosis. J. Biol. Chem. 272:6677-6684.

Mundy, J., Yamaguchi-Shinozaki, K., and Chua, N. H., 1990. Nuclear proteins bind conserved elements in the abscisic acid-responsive promoter of a rice rab gene. Proc. Natl. Acad.Sci. U.S.A. 87:1406-1410.

Munoz, J. A., Palomares, A. J., and Ratet, P. 1996. Plant genes induced in the Rhizobium-legume symbiosis. World J. Microbiol. Biotechnol. 12:189-202.

Nap, J. P., and Bisseling, T. 1990. Developmental biology of a plantprokaryote symbiosis: The legume root nodule. Science 250:948-954.

Nuc, K., Nuc, P., and Pawełkiewicz, J. 1993. The nucleotide sequence and organization of nuclear 5S rRNA genes in yellow lupine. Bull. Pol. Acad. Sci. 41:103-106.

Nuc, P., Nuc, K., Szweykowska-Kulinska, Z., and Pawełkiewicz, J. 1997. Nucleotide sequence of nuclear tRNAGly genes and tRNAGly pseudogenes from yellow lupine (Lupinus luteus): Expression of the tRNA Gly genes in vitro and in vivo. Acta Biochim. Pol. 44:259-274.

Pearson, W. R., and Lipman, D. J. 1988. Improved tools for biological sequence comparison. Proc. Natl. Acad. Sci. U.S.A. 85:2444-2448.

Perisic, O., Xiao, H., and Lis, J. T. 1989. Stable binding of Drosophila heat shock factor to head-to-head and tail-to-tail repeats of a conserved 5-bp recognition unit. Cell 59:797-806.

Pichon, M., Journet, E.-P., Dedieu, A., de Billy, F., Truchet, G., and Barker, D. G. 1992. Rhizobium meliloti elicits transient expression of the early nodulin gene ENOD12 in the differentiating root epidermis of transgenic alfalfa. Plant Cell 4:1199-1211.

Pichon, M., Journet, E.-P., de Billy, F., Dedieu, A., Huguet, T., Truchet, G., and Barker, D. G. 1994. ENOD12 gene expression as a molecular marker for comparing Rhizobium-dependent and -independent nodulation in alfalfa. Mol. Plant-Microbe Interact. 7:740-747.

Price, E., Zydowsky, L., Jin, M., Bacer, C., McKeon, F., and Walsh, C. 1991. Human cyclophilin B: A second cyclophilin gene encodes a peptidyl-prolyl isomerase with a signal sequence. Proc. Natl. Acad. Sci. U.S.A. 88:1903-1907.

Rahfeld, J. U., Schierhorn, A., Mann, K., and Fischer, G. 1994. A novel peptidylprolyl cis/trans isomerase from Escherichia coli. FEBS (Fed. Eur. Biochem. Soc.) Lett. 343:65-69.

Ramlov, K. B., Laursen, N. B., Stougaard, J., and Marcker, K. A. 1993. Site-directed mutagenesis of the organ-specific element in the soy- bean leghemoglobin lbc3 gene promoter. Plant J. 4:577-580.

Rassow, J., Mohrs, K., Koidl, S., Barthelmess, I., Pfanner, N., and Tropschug, M. 1995. Cyclophilin 20 is involved in mitochondrial protein folding in cooperation with molecular chaperones Hsp70 and Hsp60. Mol. Cell Biol. 15:2654-2662.

Ryffel, B., Woerly, G., Greiner, B., Haendler, B., Mihatsch, M., and Foxwell, B. 1991. Distribution of the cyclosporine binding protein cyclophilin in human tissues. Immunology 72:399-404.

Saitou, N., and Nei, M. 1987. The neighbor-joining method: A new method for reconstructing phylogenetic trees. Mol. Biol. Evol. 4:406425.

Sanger, F. 1981. Determination of nucleotide sequence in DNA. Science 214:1205-1210.

Sambrook, J., Fritsch, E. F., and Maniatis, T. 1989. Molecular Cloning: A Laboratory Manual, 2nd ed. Cold Spring Harbor Laboratory Press, Cold Spring Harbor, NY, U.S.A.

Schreiber, S. L. 1991. Chemistry and biology of immunophilins and their immunosuppressive ligands. Science 251:283-287.

Sherrier, D. J., and VandenBosch, K. A. 1994. Localization of repetitive proline-rich proteins in the extracellular matrix of pea root nodules. Protoplasma 183:148-161.

Shinozaki, K., and Yamaguchi-Shinozaki, K. 1997. Gene expression and signal transduction in water-stress response. Plant Physiol. 115:327334.

Siekierka, J. J., Staruch, M. J., Hung, S. H., and Sigal, N. H. 1989. FK506, a potent novel immunosuppressive agent, binds to a cytosolic protein which is distinct from the cyclosporin A-binding protein, cyclophilin. J. Immunol. 143:1580-1583.

Stewaet, D. E., Sarkar, D. B., and Wampler, J. E. 1990. Occurrence and role of cis peptide bonds in protein structure J. Mol. Biol. 214:253260.

Sykes, K., Gething, M. J., and Sambrook, J. 1993. Proline isomerases function during heat shock. Proc. Natl. Acad. Sci. U.S.A. 90:58535857.

Thompson, J. D., Higgins, D. G., and Gibson, T. J. 1994. Clustal W: Improving the sensitivity of progressive multiple sequence alignment through sequence weighting, position-specific gap penalties, and weight matrix choice. Nucleic Acids Res. 11:4673-4680.

Udvardi, M. K. 2001. Legume models strut their stuff. Mol. PlantMicrobe Interact. 14:6-9.

Ulmasov, T., Liu, Z.-B., Hagen, G., and Guilfoyle, T. J. 1995. Composite structure of auxin response elements. Plant Cell 7:1611-1623.

Ulmasov, T., Hagen, G., and Guilfoyle, T. J. 1997. ARF1, a transcription factor that binds auxin response elements. Science 276:1865-1868.

Van de Wiel, C., Scheres, B., Franssen, H., Van Lierop, M. J., Van Lammeren, A., van Kammen, A., and Bisseling, T. 1990. The early nodulin transcript ENOD2 is located in the nodule parenchyma (inner cortex) of pea and soybean root nodules. EMBO (Eur. Mol. Biol. Organ.) J. 9:1-7.

van Kammen, A. 1984. Suggested nomenclature for plant genes involved in nodulation and symbiosis. Plant Mol. Biol. Rep. 2:43-45.

Wilson, R. C., Long, F., Miko Maruoka, E., and Cooper, J. B. 1994. A new proline-rich early nodulin from Medicago trunculata is highly expressed in nodule meristematic cells. Plant Cell 6:1265-1275.

Wu, J., Matunis, M. J., Kraemer, D., Blobel, G., and Coutavas, E. 1995. Nup358, a cytosolically exposed nucleoporin with peptide repeats, Ran-GTP binding sites, zinc fingers, a cyclophilin A homologous domain, and a leucine-rich region. J. Biol. Chem. 270:14209-14213.

Wyatt, R. E., Nagao, R. T., and Key, J. L. 1992. Patterns of soybean proline-rich protein gene expression. Plant Cell 4:99-110.

Ye, Z. H., Song, Y. R., Marcus, A., and Varner, J. E. 1991. Comparative localization of three classes of cell wall proteins. Plant J. 1:175-183. 